UDC: 371.212:(811.111+316.46) https://doi.org/10.22190/JTESAP2103517S

Review research paper

\title{
CHALLENGES AND ADAPTABILITY OF LANGUAGE TEACHERS TOWARDS VIRTUAL CLASSROOMS DURING COVID 19
}

\author{
Ketki Satpute \\ Sree Narayana Guru College of Education (B.Ed.), Mumbai, University of Mumbai, India
}

\begin{abstract}
The outbreak of COVID 19 has locked down entire country and created a crisis situation. It compelled all Educational Institutions to close down. To keep teachinglearning process continuing, massive shift is being observed from physical classrooms to virtual classrooms. Language plays a key role in learning. Hence meaningful language learning is a must. Creating a conducive learning environment to teach languages effectively online, necessitates the use of virtual classroom by Language Teachers. However, it may create various challenges, unless the mindset of the teachers is positive and ready to adapt to new situations. Present study aims to find out challenges faced by the language teachers and their adaptability towards online teaching during COVID pandemic. The researcher used descriptive survey method. The sample of the study included 5I language teachers teaching at college level in the state of Maharashtra. The sampling technique used was snowballing through known contacts. The tool used was questionnaire. Data was analysed through descriptive and inferential statistical techniques such percentage, mean, standard deviation, graphical representation and ' $t$ ' test. The findings of the study revealed that there is significant difference between the challenges faced by urban and rural language teachers. But no significant difference was found among urban and rural language teachers in adaptability towards virtual classroom teaching. Though teachers tried to adapt to online teaching voluntarily, proper training in the use of elearning platforms, apt digital tools for language development and development of new skill set are recommended to adapt to the new normal effectively.
\end{abstract}

Key words: Language learning, Online teaching, Virtual classroom, COVID 19

\section{INTRODUCTION}

The outbreak of COVID 19 has locked down entire country and created a crisis situation. Since the mid of March 2020 all educational institutions in India were shut down temporarily as a measure to contain the spread of novel corona virus. The pandemic has significantly disrupted the regular teaching-learning process in physical classroom. It has transformed the chalk-talk method to the one driven by technology. All educational institutions had to switch to online education so that there is no loss of learning for students and their education continues. While learning any subject, students

Submitted March $5^{\text {th }}, 2021$, accepted for publication March $20^{\text {th }}, 2021$

Corresponding author: Ketki Satpute. Sree Narayana Guru College of Education (B.Ed.), University of Mumbai, Sree Narayana Nagar, P.L.Lokhande Marg, Chembur (West), Mumbai - 400 089, India|E-mail: ketki2121 @gmail.com 
assimilate new concepts when they listen, talk, read and write about what they are learning. Hence meaningful language learning is a must. India is multilingual country which stresses the key role the language plays at all levels of education. As Altam Saleh noted, "A language is a tool that we use to communicate with each other; it may be our mother tongue, a second, or a foreign language that we learn.". Language is a base for all other learnings. Hence meaningful language learning is a must.

A massive paradigm shift to online teaching through virtual classroom is being observed at all levels of learning due to COVID crisis. Technology has always been an important part of teaching and learning environment. The pandemic situation has made it compulsory for language teachers to use online teaching mode to continue effective language teaching. A virtual classroom has become the reality of today's education scenario. "A virtual classroom is a place where people can teach and learn interactively, communicate, view and discuss presentations and engage with learning resources while working in groups, all in an online environment." ${ }^{2}$ The virtual classroom crosses the boundaries of location, time and space providing a flexible leaning environment for all.

However, migrating from traditional learning to fully virtual and online mode has posed many challenges for language teachers. Unless the mindset of the teacher is positive and ready to adapt to new crisis situation, a sudden shift towards online teaching is difficult. The unprecedented situation has posed many challenges with many questions at this stage remaining unanswered. Are the language teachers ready to face the challenges of online language teaching and adapt to virtual classrooms during COVID 19 ? With this research question in mind, the researcher aims to find out the adaptability of language teachers towards online teaching during COVID pandemic. The paper emphasises on the challenges faced by the language teachers while implementing elearning platforms and teaching language in virtual classrooms.

\section{METHODOLOGY}

The present study used descriptive survey method. An online survey was conducted during the lock down period of COVID 19 between $12^{\text {th }}$ June to $26^{\text {th }}$ June 2020 in the state of Maharashtra, India.

\subsection{Statement of the Problem}

Challenges and adaptability of language teachers towards virtual classroom during COVID 19.

\subsection{Aim of the Study}

To study the challenges and adaptability towards virtual classroom by language teachers during COVID 19.

\subsection{Objectives of the Study}

1. To study the challenges faced by language teachers and their adaptability towards virtual classroom during COVID 19.

2. To study the significant difference in the challenges and adaptability of language teachers towards virtual classroom during COVID 19 with respect to geographical area. 


\subsection{Hypotheses of the study}

1. There is no significant difference between the challenges faced by language teachers towards virtual classroom during COVID 19 on the basis of geographical area.

2. There is no significant difference between the adaptability of language teachers towards virtual classroom during COVID 19 on the basis of geographical area.

\subsection{Sample of the study}

The sample selected was language teachers teaching at college level in the state of Maharashtra. The sampling technique used was snowballing through known contacts. The sample size was 51 language teachers. It included $82 \%$ language teachers from urban area and $18 \%$ from rural area of Maharashtra.

\subsection{Tool of the study}

A Questionnaire was used as a tool to collect the data through Google form. The tool consists of 18 items out of which 13 were closed ended questions and 5 items were designed according to five-point Likert Scale to know the opinion of participants towards challenges faced by them and adaptability towards virtual classroom. The tool was administered via email and social media platforms to get the responses from the target group.

\subsection{Techniques of data analysis}

The present research used the statistical techniques such as Percentage, Mean, Standard deviation, Graphical presentation and t-test for analysis of the data.

\section{RESULTS AND DISCUSSION}

An analysis of the results, gives us the understanding of the various challenges encountered by the language teachers to shift towards online virtual classes during lockdown period without any preparation and the efforts taken by them to adapt to this new normal situation created by pandemic crisis. The subtitles that follow pertain to the questions that were asked to participants and it discusses the results in detail. Further it tests the hypotheses of the study.

\subsection{Virtual classrooms and lack of Technical skills}

Teaching in a virtual classroom during lock-down period was considered as a challenge by $53 \%$ (27), an opportunity by $39 \%$ (20) and a burden by $7.8 \%$ (4) teachers. All the teachers in rural area considered it as a challenge (53\% includes rural teachers), whereas $35 \%$ of urban teachers considered it a challenge and $39 \%$ took it as an opportunity. Majority of the teachers (76\%) were of the opinion that shifting from physical classroom to virtual classroom is essential to continue the teaching-learning process during lock-down, $20 \%$ were not sure of it and only $4 \%$ believed that it is not essential. But while checking on preparedness for technical skills required for online teaching it was found that majority of them were not prepared at all or prepared to some extent and only $27.5 \%$ were well prepared to conduct online teaching. This clearly shows 
that though majority teachers were willing to shift to online teaching, they were unprepared and lacked the technical skills required for it which was the major hurdle in smooth conduct of virtual classroom. As published in 'The Tribune', 'according to new research revealed by UNESCO's teacher task force, an estimated 2.7 million teachers in India who have been impacted by the coronavirus lockdown are untrained to deal with the altered situation.' 3 This highlights the need of training the teachers to cope up with the challenge of online teaching.

Majority (74\%) of the teachers were asked by their institution to teach online during lock down period. For $10 \%$ teachers online teaching was optional whereas $16 \%$ did not receive any instructions for conducting online teaching. Technical constraints such as internet connectivity, power cuts, availability of gadgets for uninterrupted online teaching were faced, sometimes by $70 \%$, Always by $16 \%$ (includes $100 \%$ rural area), Rarely by $10 \%$ and Not at all by $4 \%$ teachers. It is noticeable that technical constraint disrupts the online teaching in both rural and urban area causing frustration and pressure among language teachers. As Susan Sun has stated in her study 'Time zones, Internet connectivity and bandwidth, technical breakdowns, individual students' schedules (work vs. study), etc. are all real issues facing online teachers and learners.' ${ }^{4}$

\subsection{Awareness of e-learning platforms and digital tools}

The orientation of teachers and students on the use of e-learning platforms prior to actually conducting online class was considered essential by $86.3 \%$ teachers. Though use of technology in language learning is not new, but sudden shift from physical classroom to virtual classroom without any proper training or orientation towards the use of elearning platform, unpreparedness towards technical skills was a challenge for the language teachers. The result of De Paepe et al. agrees that 'acquiring technical skills prior to switching to virtual classroom is a must." 5

In a traditional language classroom, teachers facilitate the learning experiences which prompts the peers to interact spontaneously. For successful language learning, participation of learners and interaction with them is of crucial importance. For interactive virtual language classroom knowledge of various e-platforms, digital tools and its apt use at proper time for developing various language skills is a must. The results of awareness of using e-learning platforms prior to lockdown shows that the most known elearning platforms were Zoom app (39\%), Google classroom (39\%), Google Meet (27\%), followed by Edmodo (6\%), Moodle (6\%), Microsoft Team (5\%) and Cisco WebEx (5\%). But $23.5 \%$ were not at all aware of any of the e-learning platforms which poses a big challenge for conducting a virtual language classroom.

It was also observed in a survey that very few teachers were aware of the digital tool such as Thing Link (7\%), Kahoot (7\%), H5P Applications (4\%), Podcast (11\%) etc. and hardly use them in their virtual classroom for making the language learning more interactive and student centric. You Tube videos (61\%) and Interactive PPT (59\%) were the most used digital tools in the classrooms, which may not be sufficient to engage the students. Surely, teachers need proper orientation to online teaching and knowledge of various digital tools, specifically for online language class and its effective use to make language learning more interactive. De Paepe et al. also stated that professional development is perceived necessary to acquire the indispensable technical and pedagogical skills. $^{6}$ 
Table 1 gives descriptive data analysis of Likert scale items on challenges and adaptability of language teachers towards virtual classroom.

Table 1 Descriptive data analysis of challenges and adaptability of language teachers

\begin{tabular}{|l|c|c|c|c|c|c|c|}
\hline \multirow{2}{*}{ Questionnaire Items } & \multicolumn{3}{|c|}{ Participant's Responses (in \%) } & Mean & S.D. \\
\cline { 2 - 7 } & $\begin{array}{c}\text { Strongly } \\
\text { Agree }\end{array}$ & Agree & Neutral & Disagree & $\begin{array}{c}\text { Strongly } \\
\text { Disagre }\end{array}$ & & \\
\hline $\begin{array}{l}\text { 1. Necessity of orientation to e- } \\
\text { learning platforms prior } \\
\text { online class. }\end{array}$ & 86.3 & 2 & 9.8 & 2 & - & 4.72 & 0.72 \\
\hline $\begin{array}{l}\text { 2. Difficulty } \\
\text { in developing } \\
\text { e-content }\end{array}$ & 45.1 & 7.8 & 27.5 & 11.8 & 7.84 & 3.70 & 1.36 \\
\hline $\begin{array}{l}\text { 3. Difficulty in continuous } \\
\text { engagement of students in } \\
\text { virtualclassroom. }\end{array}$ & 70.6 & 9.8 & 7.8 & 11.8 & - & 4.39 & 1.05 \\
\hline $\begin{array}{l}\text { 4. Monitoring of online } \\
\text { assessment is roadblock to } \\
\text { online language teaching. }\end{array}$ & 56.9 & 13.7 & 21.6 & 5.8 & 2 & 4.17 & 1.09 \\
\hline $\begin{array}{l}\text { 5. Continuation of online } \\
\text { teaching after lock-down } \\
\text { gets over. }\end{array}$ & 51 & 2 & 37.3 & 5.8 & 4 & 3.90 & 1.22 \\
\hline
\end{tabular}

\subsection{Face to face interaction and Student engagement}

From Table 1(item 3), it is evident that $70.6 \%(\mathrm{M}=4.39)$ of the teachers found it difficult to keep students engage continuously in a virtual language classroom. This corroborates with the results, "Student engagement and the facilitation of collaboration among students is perceived difficult and that online teachers need to make a shift towards an individualized, learner-centred teaching model."7 In a normal physical classroom, body language, facial expressions, and teachers' voice are all important teaching tools. At the same time, emotional engagement, bonding and verbal communication with students, makes language learning more effective. In a virtual classroom it may be missing. "Once a course is switched to online teaching, body language and facial expressions are under restrictions as it is difficult to use these tools through screens, and only "voice" could be fully functioned." 8

14. While teaching language discourse in a virtual classroom, I miss the following things 51 responses

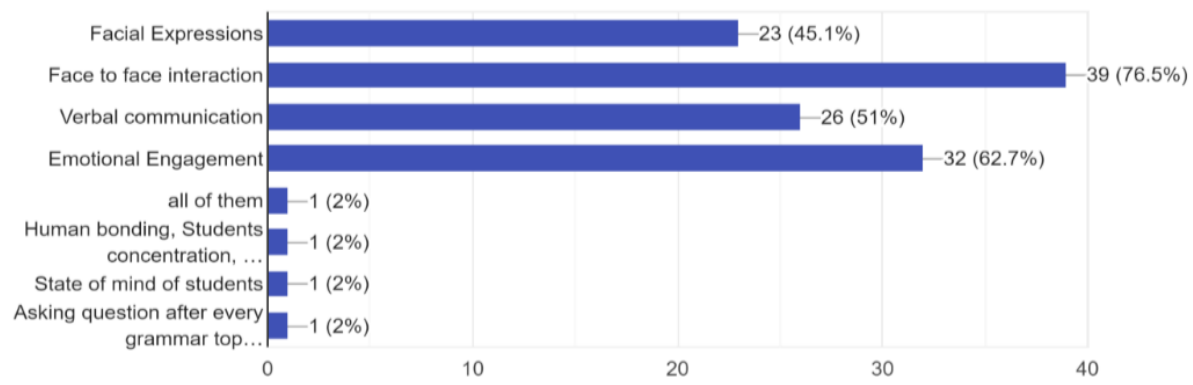

Fig. 1 The most missed things in virtual language class 
The Bar Graph above (Figure 1), clearly shows that in a virtual language classroom teacher misses face to face interaction $(76.5 \%)$ the most, followed by Emotional Engagement (62.7\%), Verbal communication (51\%), and Facial Expression (45.1\%). As stated by Sun in her study "Even if a teacher manages to have students all coming to the virtual classroom at the same time, simple things such as the loss of lip synchronization and verbal clues, time lags, poor sound and images, turn-taking, etc. become huge challenges." 9 The results in the present study shows that few language teachers also miss the interaction, human bonding with the students and their state of mind during virtual classroom sessions.

\subsection{Language Skills}

"Language learning is a skill-based process rather than a content-based one. Skill developments, such as the acquisition of speaking and listening skills, required constant synchronous interaction in the target language." 10 The development of listening, speaking, reading and writing skills are equally important for any language learning. The results in the present study show that the use of digital tools in a virtual classroom improves the listening skill the most $(82.4 \%)$, followed by speaking skill $(7.8 \%)$, reading skill $(7.8 \%)$ and the least developed is writing skill $(2 \%)$. It emphasizes the need to develop the digital tools which can be used by all the language teachers catering to development of all the language skills equally.

\subsection{E-content and Online assessment}

It was observed that conducting examination (39.2\%) and doing assessment $(35.3 \%)$ were the most difficult part of virtual language classroom than teaching $(11.8 \%)$ and learning $(13.7 \%)$. The pie chart below shows the percentage of the responses for the most difficult part in a virtual classroom of a language.
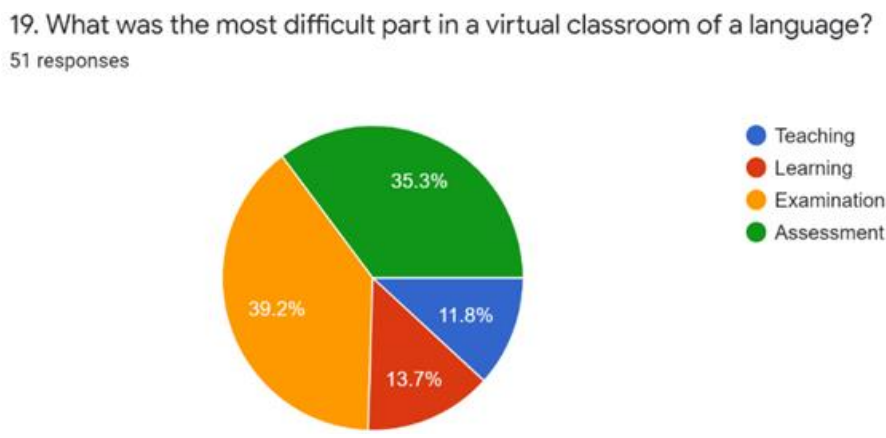

Fig. 2 The most difficult part in a virtual language class

Only conduct of online lectures in a virtual classroom is not sufficient, it also requires sufficient e-content, online study material, spreadsheets, practice sheets etc. so that students can access them easily. It is very essential that along with online teaching-learning process, the student's progress is also being tracked with timely conduct of examination and proper evaluation through online modes in this situation of pandemic. Teachers need to be conversant with procedure of e-content development and proper use of various digital tools 
for assessment. It can be seen from Table 1(item 2), 53\% teachers found development of econtent, a tedious work. But there are $27 \%$ who remained neutral, maybe they haven't yet developed any e-content and for $20 \%$ teachers e-content development was not tedious work. It is also observed that $70 \%$ of the teachers agree that monitoring of online assessment is the roadblock to effective online language teaching which can be seen in Table 1 (item 4). Very few teachers use any digital assessment tools such as Classmarker (17.6\%), Blog (9.8\%), Animoto (3.9\%), Rubrics(9\%). The most used is Google form (53\%), but alarming $43 \%$ teachers do not use any of these assessment tools which shows their ignorance and lack in digital competence. In Sun's study she quoted Compton $(2009$, p.82) that a novice online language teacher must learn and possess the knowledge of strategies to facilitate communicative competence and online interaction, curriculum design frameworks and strategies for online language assessment. ${ }^{11}$

\subsection{Adapting to virtual classrooms}

As there was no other option but to conduct virtual language classes during pandemic, teachers have taken various efforts to adapt themselves to new normal i.e., virtual learning by attending Faculty development programs (62.7\%), Webinars $(60.8 \%)$, Practice and implementing e-learnings (49\%), Self-learning $(68.6 \%)$ etc. They agree that pandemic situation has given them an opportunity to develop themselves and their skills, by shifting to online teaching, such as Technical skills (84.3\%), Professional Development (45\%), Adapting to new teaching culture (68.6\%), Pedagogy skills (31.4) and it is also observed from Table 1 (item 5 ) that $53 \%$ teachers would continue the trend of online teaching even after lock-down period is over to make language learning more interactive. Overall, it can be said that traditional professional expertise i.e., competence in language, pedagogical knowledge, experience in teaching language is not suffice to survive in new normal. "Synchronous online teaching requires a new and extended skills set." 12 Online teaching requires technological knowledge and awareness of web-based tools along with pedagogical and content knowledge. It needs a distinct set of skills to be used in virtual classroom. Teachers need proper training and exposure to digital tools to adapt to virtual classroom successfully.

\subsection{Testing of Hypothesis 1}

There is no significant difference between the challenges faced by language teachers towards virtual classroom during COVID 19 on the basis of their geographical area.

Table 2 Relevant statistics of challenges of language teachers on the basis of their geographical area

\begin{tabular}{|l|c|c|c|c|c|c|c|c|}
\hline Variable & Geographical area & $\mathrm{N}$ & Mean & SD & df & 't' value & P & $\begin{array}{c}\text { Significance } \\
(0.05 \text { level })\end{array}$ \\
\hline $\begin{array}{l}\text { Challenges of } \\
\text { language teachers }\end{array}$ & Urban & 42 & 3.90 & 1.32 & 49 & 2.35 & 0.02 & Significant \\
\cline { 2 - 7 }
\end{tabular}

For above Table 2 , for $\mathrm{N}=51, \mathrm{df}=49$, tabulated $\mathrm{t}=2.01$ at 0.05 level

From Table 2, it can be seen that the obtained ' $t$ ' value is 2.35 which is greater than tabulated ' $\mathrm{t}$ ' value and ' $\mathrm{p}$ ' values is less than 0.05 , hence it is significant. That means 
hypothesis is not accepted. Therefore, there exists significant difference between the challenges of language teachers on the basis of their geographical area.

The findings of the above reveal that language teachers working in rural areas face many challenges as compared to urban language teachers. Inadequate infrastructure facilities, technical constraints such as internet connectivity, bandwidth, availability of devices during lock-down, unawareness of e-learning platforms and digital tools for language teaching and development of e-content, could be the challenges that language teachers face in rural areas. In Susan Sun's study she mentioned, 'It seems that online teachers are, by and large, left to do their own experiments and perhaps learn from their own mistakes. ${ }^{13}$ This emphasises proper guidance and training to language teachers prior shifting to virtual classroom.

\subsection{Testing of Hypothesis 2}

There is no significant difference between the adaptability of language teachers towards virtual classroom during COVID 19 on the basis of their geographical area.

Table 3. Relevant statistics of the adaptability of language teachers on the basis of their geographical area

\begin{tabular}{|c|c|c|c|c|c|c|c|c|}
\hline Variable & Geographical area & $\mathrm{N}$ & Mean & SD & $\mathrm{df}$ & 't' value & $P$ & $\begin{array}{l}\text { Significance } \\
(0.05 \text { level })\end{array}$ \\
\hline \multirow{2}{*}{\begin{tabular}{|l|} 
Adaptability of \\
language teachers
\end{tabular}} & Urban & 42 & 4.76 & 0.69 & \multirow{2}{*}{49} & \multirow{2}{*}{0.77} & \multirow{2}{*}{0.44} & \multirow{2}{*}{ Non significant } \\
\hline & Rural & 9 & 4.55 & 0.88 & & & & \\
\hline
\end{tabular}

For above Table 3 , for $\mathrm{N}=51, \mathrm{df}=49$, tabulated $\mathrm{t}=2.01$ at 0.05 level

For the above hypothesis 'p' value is greater than 0.05 . Hence it is not significant. That means hypothesis is accepted. Therefore, there does not exist a significant difference in the adaptability of language teachers towards virtual classroom on the basis of their geographical area.

Though the lock-down period has forced the teachers to shift to online teaching and virtual classroom without any proper training, it has also provided an opportunity for many teachers to improve their technical and pedagogical skills by attending various workshops, seminars, conferences etc. To continue teaching-learning process without any hinderance teachers from both urban and rural area have taken various efforts to adapt themselves to new normal by self-learning. It shows that geographical area does not influence the adaptability towards virtual classroom.

\section{CONCLUSION}

Due to sudden emergence of COVID-19, new normal has emerged, a virtual classroom. This study conducted the survey of 51 language teachers in Maharashtra and found insightful information regarding the challenges faced and adaptations made by the language teachers while conducting virtual language class. Unpreparedness, Lack of proper training, Technical constraints were found as common challenges, both in urban and rural area of Maharashtra. Unawareness of e-learning platforms and digital tools for language teaching, developing e-content, engaging students in virtual classroom, development of language skills specially writing skill, monitoring online assessment were seen as major challenges in present study. Language teachers in rural areas had to face these challenges more as digital 
tools and content are readily available in English language. Hence adapting to online teaching is easier for teachers teaching English language. Teachers teaching other regional languages had to work hard and put efforts in overcoming the challenges. Proper infrastructure facilities and technical support in rural areas, training in the use of e-learning platforms, apt digital tools for language development and development of new skill set are recommended to adapt to the new normal. Infusing creative ideas and innovation while creating new online language material and facilitating online transaction is the need of the hour. A competent teacher is the one who transforms challenges into opportunities and is ready to learn, unlearn and relearn. Developing positive mind set among language teachers and a fresh new approach towards virtual classroom teaching will help survive this storm of COVID 19 in education. The findings of this study will make teachers aware the practical problems of online language teaching and help all other language teachers to prepare in advance and adapt successfully to virtual classrooms. It will also give insight to Educational Institutions for conducting the apt and necessary orientations, workshops, webinars, faculty development programs required by the language teachers to develop new set of skills.

\section{REFERENCES}

1. Altam Saleh, "Influence of Social Media on EFL Yemeni Learners in Indian Universities during Covid-19 Pandemic," Linguistics and Culture Review, 4(1), (May 2020):36, Accessed 15 June 2020, https://doi.org/10.37028/lingcure.v4n1.19

2. Murugachandravel J, "Trends in Virtual Classrooms," Global Research and Development Journal of Engineering, ” vol.4(7) (June 2019):16. ISSN: 2455-5703, Accessed 8 June 2020.

3. The Tribune, "2.7 million teachers in India untrained to deal with covid challenges to education", May 28, 2020. Retrieved from https://www.tribuneindia.com/news/ schools/2-7-million-teachers-in-india-untrained-to-deal-with-covid-challenges-toeducation-91151

4. Susan Sun, "Online Language Teaching: The Pedagogical Challenges," Knowledge Management \& E-Learning: An International Journal, vol.3(3) (2011):431, ISSN: 20737904, Accessed 15 June 2020, doi: 10.34105/j.kmel.2011.03.030

5. De Paepe, Liesbeth, et al, "Online Language Teaching: Teacher Perceptions of Effective Communication Tools, Required Skills and Challenges of Online Teaching," Journal of Interactive Learning Research, vol. 29(1)(2018):129.

6. Ibid., 129.

7. Ibid., 129.

8. Bao Wei, "COVID -19 and Online Teaching in Higher Education: A Case Study of Peking University," Human Behavior and Emerging Technologies, vol.2(2) (March 2020): 114, doi:10.1002/hbe2.191.

9. Sun, "Online Language Teaching: The Pedagogical Challenges," 431.

10. Ibid., 439.

11. Sun, "Online Language Teaching: The Pedagogical Challenges", 430.

12. Benjamin Luke Moorhouse, "Adaptation to a face-to-face initial teacher education course 'forced' online due to COVID-19 pandemic", Journal of Education for Teaching (15 April 2020):3, Accessed 22 June 2020, DOI 10.1080/02607476. 2020.1755205 .

13. Sun, "Online Language Teaching: The Pedagogical Challenges", 431 


\section{BIBLIOGRAPHY}

J, Murugachandravel. "Trends in Virtual Classrooms." Global Research and Development Journal of Engineering, vol. 7, (June 2019):16-18, ISSN: 2455-5703.Accessed 8 June2020. https://www.grdjournals.com/uploads/article/GRDJE/V04/I07/0011/ GRDJEV04I070011.pdf

Moorhouse, B. "Adaptation to face to face initial teacher education course 'forced' online due To COVID 19 pandemic.” Journal of Education for Teaching (15 April 2020):1-4 Accessed 22 June 2020 DOI 10.1080/02607476.2020.1755205.

Paepe De, Liesbeth, et al. "Online Language Teaching: Teacher Perceptions of Effective Communication Tools, Required Skills and Challenges of Online Teaching." Journal of Interactive Learning Research, vol. 29, no. 1, 2018, pp. 129-42.

Saleh, Altam. "Influence of Social Media on EFL Yemeni Learners in Indian Universities during Covid-19 Pandemic." (May 2020):35-47. Accessed 15 June 2020. https://doi.org/10.37028/lingcure.v4n1.19

Sun, Susan. "Online Language Teaching: The Pedagogical Challenges." Knowledge Management \& E-Learning: An International Journal, vol.3, no. 3, pp. 428-447. Accessed 15 June 2020.

The Tribune, "2.7 million teachers in India untrained to deal with covid challenges to education", May 28, 2020. https://www.tribuneindia.com/news/schools/2-7-millionteachers-in-india-untrained-to-deal-with-covid-challenges-to-education-91151

Wei, Bao. "COVID -19 and Online Teaching in Higher Education: A Case Study of Peking University." Human Behavior and Emerging Technologies, vol. 2, no. 2, 2020, pp. 113-15, doi:10.1002/hbe2.191. https:/www.tribuneindia.com/news/schools/2-7million-teachers-in-india-untrained-to-deal-with-covid-challenges-to-education-91151 